\title{
KAJIAN TINGKAT KEPUASAN PENGGUNA JASA TERHADAP KINERJA PELAYANAN ANGKUTAN PENYEBERANGAN LINTAS KARIANGAU - PENAJAM, BALIKPAPAN
}

\section{Study of Costumer Satisfaction Level of Ferry Service Performance of Kariangau - Penajam Trajectory, Balikpapan}

\author{
Darmadi $^{1}$, Muhammad Zainul Arifin ${ }^{2}$, Imma Widyawati Agustin ${ }^{3}$ \\ 1,2Jurusan Teknik Sipil - Fakultas Teknik - Universitas Brawijaya \\ Jl. MT. Haryono No.167, Malang 65145, Jawa Timur \\ Email: 1idamrad@gmail.com; ${ }^{2}$ mzaftub@gmail.com \\ ${ }^{3}$ Jurusan Teknik Perencanaan Wilayah dan Kota - Fakultas Teknik - Universitas Brawijaya \\ Jl. MT. Haryono No.167, Malang 65145, Jawa Timur \\ Email: ${ }^{3}$ immasaitama@ub.ac.id
}

\begin{abstract}
The objectives of this study are for knowing costumer satisfaction level of ferry service performance Kariangau- Penajam trajectory, Balikpapan based on customer perception with existence of change of ship operational system from 8:4 (8 ship operated and 4 standby) become 10:2 (10 ship operated and 2 standby) and also for getting alternative solution to overcome problems which there is still after imposed of new ship operational system. This study uses Importance-Performance Analysis (IPA) and Customer Satisfaction Index (CSI)methods. Result of study pursuant to analysis of IPA quadrant, service attributes becoming major priority to be improve repaired by its performance are attribute hygiene of bath room/toilet in ship, accuracy of arrival time in destination port, accuracy of time voyage duration, condition of air circulation in ship and demonstration of usage of safety appliance in ship. CSI calculation result based on customer perception obtained value $69 \%$ that representation that assessment of respondent to ferry service performance of Kariangau - Penajam trajectory enter in satisfied category.
\end{abstract}

Keywords: service-performance, crossing-transport, Importance-Performance-Analysis, Customer-Satisfaction-Index

\begin{abstract}
Abstrak
Tujuan kajian ini adalah untuk mengetahui tingkat kepuasan pengguna jasa terhadap kinerja pelayanan angkutan penyeberangan lintas Kariangau - Penajam, Balikpapan berdasarkan persepsi pengguna jasa dengan adanya perubahan pola operasional kapal dari pola 8:4 (8 kapal operasi dan 4 standby) menjadi pola 10:2 (10 kapal operasi dan 2 standby) dan mendapatkan solusi alternatif untuk mengatasi permasalahan yang masih ada setelah diberlakukannya sistem operasional kapal yang baru. Kajian ini menggunakan metode Importance-Performance Analysis (IPA) dan Customer Satisfaction Index (CSI). Hasil analisis kuadran IPA, atribut pelayanan yang menjadi prioritas utama untuk diperbaiki kinerjanya adalah atribut kebersihan kamar mandi/WC di kapal, ketepatan waktu tiba di pelabuhan tujuan, ketepatan waktu lamanya perjalanan, kondisi sirkulasi udara di kapal dan peragaan pemakaian alat keselamatan di kapal. Hasil perhitungan CSI berdasarkan persepsi pengguna jasa diperoleh nilai $69 \%$ yang merepresentasikan bahwa penilaian pengguna jasa terhadap kinerja pelayanan angkutan penyeberangan lintas Kariangau Penajam masuk dalam kategori Puas.
\end{abstract}

Kata kunci: kinerja-pelayanan, angkutan-penyeberangan, Importance-Performance-Analysis, Customer-Satisfaction-Index

\section{PENDAHULUAN}

Angkutan penyeberangan didefinisikan sebagai angkutan yang fungsinya sebagai jembatan penghubung jaringan jalan dan atau jaringan jalur kereta api yang terpisahkan oleh perairan untuk mengangkut penumpang dan kendaraan beserta muatannya. Berdasarkan hal tersebut, pada dasarnya angkutan penyeberangan merupakan bagian dari angkutan jalan raya karena angkutan penyeberangan merupakan bagian penghubung jaringan transportasi darat yang berupa jalan raya ataupun kereta api yang terpisahkan oleh perairan. Berdasarkan hal 
tersebut diharapkan angkutan penyeberangan mempunyai kriteria mendekati sifat-sifat angkutan jalan raya (Fitriani, 2011) yaitu:

- Pelayanan ulang-alik dengan frekuensi yang tinggi, pelayanan tanpa waktu tunggu yang lama;

- Pelayanan terjadwal dengan headway konstan;

Pelayanan yang reliable biasanya dinyatakan dalam parameter regularity (keteraturan) dan punctually (ketepatan waktu);

- Pelayaran yang aman dan nyaman;

- Tarif yang moderat; dan

- Aksesibilitas ke pelabuhan angkutan penyeberangan yang tidak terlalu jauh dari pusat bangkitan lalu lintas.

Moda transportasi penyeberangan memiliki karakteristik mampu mengangkut penumpang dan kendaraan dalam jumlah besar serta dengan kecepatan relatif rendah dengan tingkat polusi yang rendah (Adisasmita, 2013). Jaringan pelayanan transportasi penyeberangan disebut dengan lintas penyeberangan. Lintas penyeberangan Kariangau - Penajam merupakan lintas penyeberangan antar kota/kabupaten yang ada di propinsi Kalimantan Timur. Lintasan ini memiliki panjang lintasan 6 mil laut dan menghubungkan dua wilayah, kota dan kabupaten yaitu kota Balikpapan dan kabupaten Penajam Paser Utara (PPU). Lintas Kariangau Penajam merupakan lintas komersil dalam propinsi yang ditetapkan berdasarkan Keputusan Menteri Perhubungan Nomor KM. 64 Tahun 1989 tentang Lintas Penyeberangan.

Dengan menggunakan moda transportasi penyeberangan, Balikpapan - Penajam saat ini dapat ditempuh dalam waktu kurang lebih satu jam dan dua belas menit.

Sebagai fasilitas umum angkutan massa, kinerja pelayanan angkutan penyeberangan sering mendapatkan sorotan dari masyarakat. Salah satunya adalah dengan masih adanya keluhan masyarakat terhadap kinerja pelayanan angkutan penyeberangan Kariangau - Penajam yang menyatakan bahwa waktu penggunaan sistem pelayanan penyeberangan lama sehingga penumpang harus antri di pelabuhan atau lama di atas kapal menunggu bongkar muat. Untuk menjawab keluhan masyarakat tersebut maka diterapkanlah pola operasional kapal yang baru untuk lintas Kariangau - Penajam yaitu pola 10:2 (10 kapal operasi dan 2 standby) dari yang sebelumnya pola 8:4 (8 kapal operasi dan 4 standby) oleh pengelola pelabuhan. Berdasarkan hal tersebut di atas, dipandang perlu adanya kajian tentang kinerja pelayanan angkutan penyeberangan lintas Kariangau - Penajam berdasarkan persepsi pengguna jasa terhadap penerapan pola sistem operasional kapal yang baru tersebut.

\section{METODE PENELITIAN}

Lokasi kajian adalah di Kota Balikpapan, Kalimantan Timur, tepatnya di pelabuhan penyeberangan Kariangau yang melayani penyeberangan lintas Kariangau - Penajam dengan fokus kajian pada kinerja pelayanan angkutan penyeberangan dalam hal ini adalah kapal - kapal penyeberangan yang melayani lintas Kariangau - Penajam dengan sistem operasional kapal 10:2 (10 kapal operasi dan 2 standby) (Gambar 1).

Data kajian yang digunakan adalah data persepsi pengguna jasa terhadap kinerja pelayanan angkutan penyeberangan lintas Kariangau-Penajam, Balikpapan. Data persepsi pengguna jasa diperoleh melalui pembagian kuesioner kepada pengguna jasa. Karena populasi jumlah pengguna jasa angkutan penyeberangan yang tidak bisa diketahui dengan pasti maka penentuan jumlah sampel untuk survei kepuasan pengguna jasa terhadap kinerja pelayanan angkutan penyeberangan menggunakan rumus pendekatan Isac Michel dan diperoleh jumlah sampel minimum 384 sampel namun untuk menghindari adanya kekurangan data digunakan 400 sampel.

Metode analisa data yang digunakan dalam kajian ini adalah metode ImportancePerformance Analysis (IPA) dan metode Customer Satisfaction Index (CSI). 


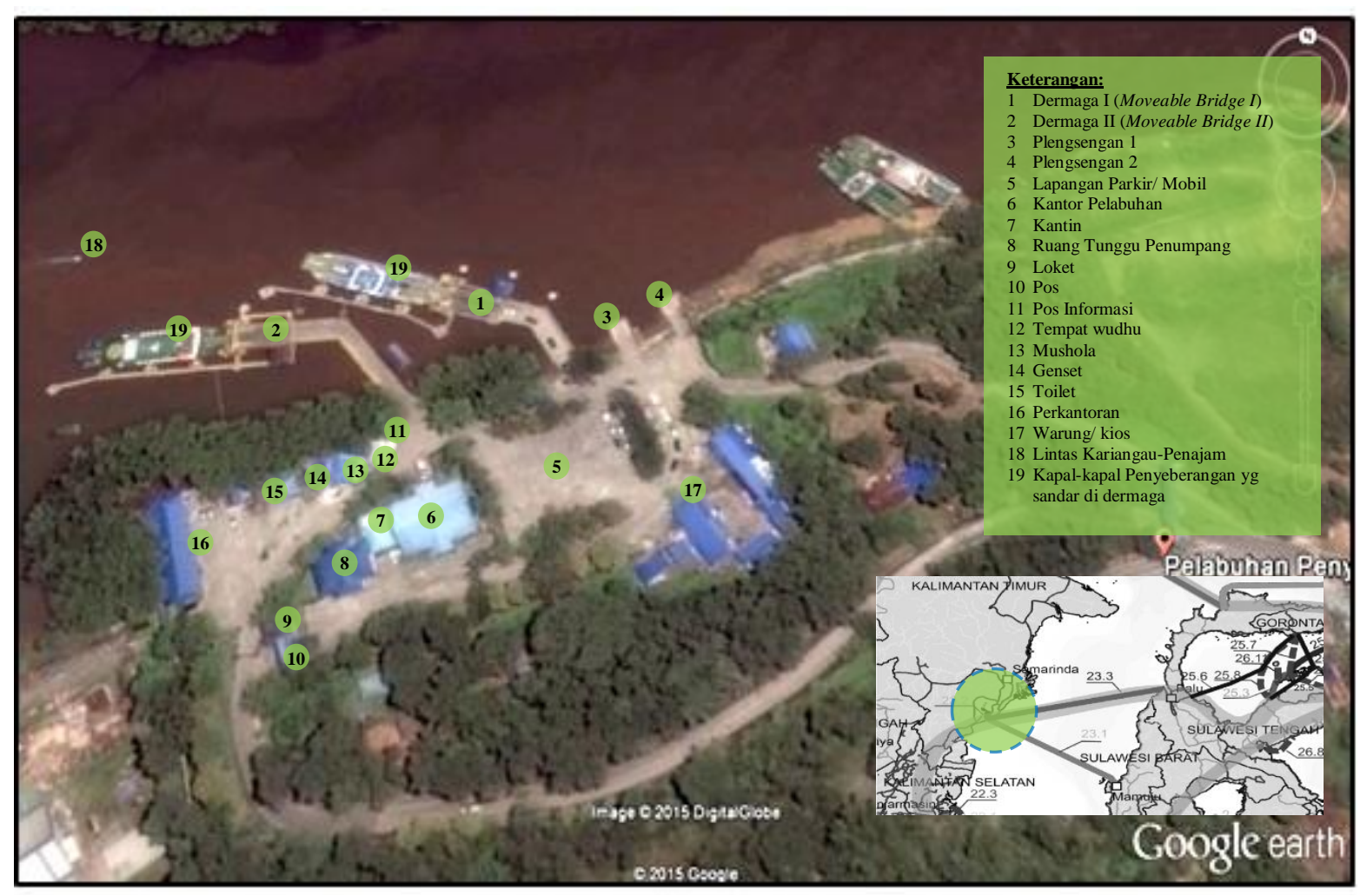

Gambar 1. Lokasi kajian

Sumber: Google Earth (2015) dan UPT. Pelabuhan Penyeberangan Kariangau, Balikpapan diolah (2015)

\section{Importance Performance Analysis}

Importance Performance Analysis (IPA) digunakan untuk mengetahui atribut-atribut pelayanan yang menurut pengguna jasa memberikan pengaruh yang besar terhadap tingkat kepuasan dan loyalitas pengguna jasa terhadap pelayanan yang mereka terima serta atribut-atribut pelayanan yang menurut pengguna jasa perlu ditingkatkan kinerjanya karena adanya perbedaan persepsi antara apa yang dirasakan dengan apa yang diharapkan. Ada pengukuran dua faktor yang digabungkan dalam metode ini, tingkat kepentingan dan tingkat kinerja yang dijabarkan ke dalam sebuah grafik dua dimensi yang memudahkan untuk penjelasan data dan usulan praktisnya. Grafik dua dimensi tersebut dapat dilihat dalam Gambar $\mathbf{2}$ dengan penjelasan sebagai berikut:

- Kuadran I (prioritas utama), atribut dalam kuadran ini memiliki tingkat kepentingan relatif tinggi dengan tingkat kinerja yang rendah, sehingga dapat dikatakan belum sesuai dengan harapan pengguna.

- Kuadran II (pertahankan prestasi), atribut dalam kuadran ini memiliki tingkat kepentingan relatif tinggi dengan tingkat kepuasan yang relatif tinggi pula sehingga keberadaannya harus tetap dipertahankan.

- Kuadran III (prioritas rendah), atribut dalam kuadran ini memiliki tingkat kepentingan yang rendah dengan kinerja nyatanya juga tidak terlalu istimewa sehingga memberikan pengaruh yang sangat kecil terhadap manfaat yang dirasakan oleh pengguna.

- Kuadran IV (cenderung berlebihan), diisi oleh atribut yang tingkat kepentingannya relatif rendah dengan kinerja yang dirasakan berlebihan.

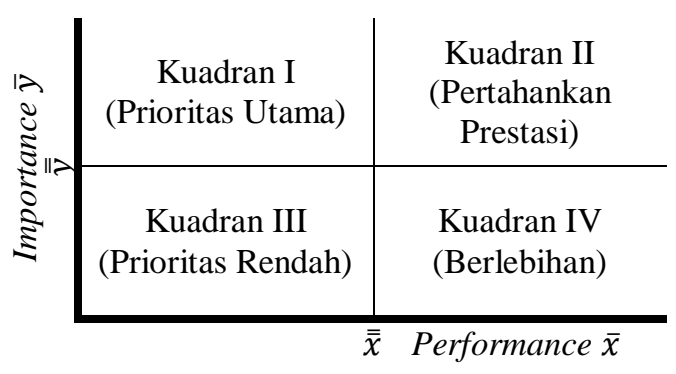

Gambar 2. Pembagian kuadran dalam IPA Sumber: Supranto, 2001

Atribut pelayanan yang digunakan untuk mengukur tingkat kepuasan pengguna terhadap kinerja pelayanan angkutan penyeberangan dalam kajian ini disajikan dalam Tabel 1. 
Tabel 1. Atribut pelayanan untuk pengukuran kinerja pelayanan angkutan penyeberangan

\begin{tabular}{cl}
\hline No. & \multicolumn{1}{c}{ Atribut Pelayanan } \\
\hline & Dimensi Tangible (berwujud) \\
1 & Kebersihan toilet di dalam kapal \\
2 & Kebersihan kapal \\
3 & Kebersihan tempat duduk yang disediakan \\
4 & Ketersediaan kantin/kafetaria di dalam \\
& kapal \\
5 & Ketersediaan tempat ibadah di dalam kapal \\
6 & Jumlah tempat duduk yang disediakan \\
7 & Ketersediaan tempat duduk setiap saat \\
8 & Kualitas tempat duduk \\
9 & Gang/ruang jalan untuk orang melintas \\
10 & Kondisi tangga di kapal \\
11 & Ketersediaan ruang perawatan (klinik) \\
& untuk orang sakit
\end{tabular}

12 Ketersediaan ruang terbuka untuk tempat santai/rekreasi (public area)

13 Ketersediaan CCTV (kamera pemantau)

14 Ketersediaan musik

15 Tarif penyeberangan

16 Penampilan kru kapal

17 Antrian kendaraan naik dan turun kapal Dimensi Reliability (kehandalan)

18 Ketepatan waktu keberangkatan

19 Ketepatan waktu tiba di pelabuhan tujuan

20 Ketepatan lama waktu pelayaran

21 Jadwal perjalanan kapal Dimensi Responsiveness (daya tanggap)

22 Kemampuan operator darat dan kru kapal dalam memberikan pelayanan secara cepat dan tepat kepada penumpang

23 Kemampuan kru kapal untuk menolong penumpang (memberikan bantuan kepada penumpang apabila dibutuhkan)

24 Kemampuan kru kapal untuk menanggapi permintaan penumpang

25 Kepedulian untuk standar pelayanan

26 Kenyamanan di dalam kapal

27 Kenyamanan dan keleluasaan tempat duduk dalam kapal

28 Suhu udara dalam kapal

29 Pengetahuan yang dimiliki kru kapal

30 Pelayanan bongkar muat kendaraan

31 Waktu bongkar muat kendaraan Dimensi Assurance (keterjaminan)

32 Kelengkapan alat-alat keselamatan di kapal

33 Adanya pemberitahuan/peragaan alat-alat keselamatan di kapal

34 Keamanan di dalam kapal

35 Keamanan barang bawaan Dimensi Empathy (empati)

36 Keramahan kru di dalam kapal

37 Perhatian secara khusus bila ada keluhan dari penumpang

38 Kepedulian operator darat dan kru kapal untuk memahami suasana hati

Sumber: Parasuraman \& Siahaan (2014)

\section{Customer Satisfaction Index}

Customer Satisfaction Index (CSI) merupakan suatu skala pengukuran yang menggambarkan tingkat kepuasan konsumen terhadap suatu produk (Ruta, 2014). Tahapan dalam perhitungan CSI adalah sebagai berikut:

- Perhitungan weighted factor yaitu mengubah skor rata-rata tingkat kepentingan dalam persen, sehingga diperoleh weighted factor total $100 \%$

- Perhitungan weighting score yaitu mengalikan skor rata-rata tingkat kinerja dengan weighted factor

- Perhitungan weighted total yaitu menjumlahkan weighted score semua atribut

- Perhitungan satisfaction index yaitu membagi weighted total dengan skala likert maksimal yang digunakan (dalam kajian ini 5) kemudian dikalikan dengan $100 \%$

Selanjutnya untuk menentukan tingkat kepuasan konsumen mengacu pada tetapan rentang nilai tingkat kepuasan dalam Tabel 2.

Tabel 2. Rentang nilai tingkat kepuasan

\begin{tabular}{cc}
\hline Rentang Nilai & Kriteria \\
\hline $0,00-0,34$ & Tidak puas \\
$0,35-0,50$ & Kurang puas \\
$0,51-0,65$ & Cukup puas \\
$0,66-0,80$ & Puas \\
$0,81-1,00$ & Sangat puas \\
\hline
\end{tabular}

Sumber: Ruta, 2014

\section{HASIL DAN PEMBAHASAN}

\section{Karakteristik Pengguna Jasa Angkutan Penyeberangan Lintas Kariangau - Penajam}

Tabel 3 menjelaskan besarnya persentase dari yang terbesar sampai yang terkecil untuk masing-masing karakteristik pengguna jasa pada tiap-tiap kategori dimana dapat diketahui bahwa sebagian besar pengguna jasa angkutan penyeberangan lintas Kariangau - Penajam, Balikpapan berusia diatas 30 tahun sampai dengan 40 tahun yang merupakan kelompok usia dewasa dan produktif, berjenis kelamin laki-laki karena mayoritas adalah pengendara kendaraan baik roda 2 maupun roda 4, sesuai data BPS Kota Balikpapan (2015) mayoritas penduduk kota Balikpapan memiliki pendidikan terakhir SMA/SMK dengan kegiatan utama bekerja. 
Mayoritas jenis pekerjaan pengguna jasa adalah sebagai karyawan swasta dengan penghasilan antara 2 juta sampai dengan 4 juta rupiah sesuai dengan Upah Minimum Kota (UMK) Balikpapan tahun 2015 yang ditetapkan yaitu sebesar Rp. 2.219.500,-.

Tabel 3. Sebaran karakteristik pengguna jasa berdasarkan kategori

\begin{tabular}{|c|c|c|}
\hline Kategori & Karakteristik & Persentase \\
\hline \multirow[t]{5}{*}{ Umur } & $>30-40$ Tahun & $31 \%$ \\
\hline & $20-30$ Tahun & $30 \%$ \\
\hline & $<20$ Tahun & $14 \%$ \\
\hline & $>40-50$ tahun & $14 \%$ \\
\hline & $>50$ tahun & $11 \%$ \\
\hline \multirow{2}{*}{ Jenis Kelamin } & Laki-laki & $75 \%$ \\
\hline & Perempuan & $25 \%$ \\
\hline \multirow{5}{*}{$\begin{array}{l}\text { Pendidikan } \\
\text { Terakhir }\end{array}$} & SMA/SMK & $47 \%$ \\
\hline & $<$ SLTP & $17,50 \%$ \\
\hline & D3 & $16,50 \%$ \\
\hline & D4/ S1 & $15,75 \%$ \\
\hline & $\mathrm{S} 2 / \mathrm{S} 3$ & $3,25 \%$ \\
\hline \multirow{6}{*}{ Pekerjaan } & Karyawan Swasta & $43 \%$ \\
\hline & Wiraswasta & $19,50 \%$ \\
\hline & Lainnya & $13 \%$ \\
\hline & $\begin{array}{l}\text { Pelajar/ } \\
\text { Mahasiswa }\end{array}$ & $11,50 \%$ \\
\hline & PNS/ ABRI & $8,75 \%$ \\
\hline & Pensiunan & $4,25 \%$ \\
\hline \multirow{4}{*}{ Penghasilan/bulan } & $>2 \mathrm{Jt}-4 \mathrm{Jt}$ & $45 \%$ \\
\hline & $>4 \mathrm{Jt}$ & $22 \%$ \\
\hline & $1 \mathrm{Jt}-2 \mathrm{Jt}$ & $18 \%$ \\
\hline & $<1$ juta & $15 \%$ \\
\hline \multirow{6}{*}{ Tujuan Perjalanan } & Bekerja & $39,75 \%$ \\
\hline & Pulang & $31,50 \%$ \\
\hline & Lain-lain & $12,75 \%$ \\
\hline & Rekreasi & $10,75 \%$ \\
\hline & Sekolah & $4,75 \%$ \\
\hline & Belanja & $0,50 \%$ \\
\hline
\end{tabular}

Sumber: Hasil Olah Data (2015)

\section{Kinerja Pelayanan Angkutan Penyeberangan Berdasarkan Persepsi Pengguna Jasa}

\section{Tingkat Kesesuaian Pengguna Jasa Angkutan Penyeberangan Lintas Kariangau-Penajam}

Tabel 4 menunjukkan total skor penilaian kinerja pelayanan angkutan penyeberangan dan kepentingan pengguna jasa terhadap atribut pelayanan yang dikaji (1-38), nilai tingkat kesesuaian pengguna jasa untuk masing-masing atribut pelayanan, urutan prioritas dan skor ratarata kinerja pelayanan angkutan penyeberangan dan kepentingan pengguna jasa.

Tabel 4. Total skor kinerja dan kepentingan, tingkat kesesuaian dan rata-rata kinerja dan kepentingan

\begin{tabular}{|c|c|c|c|c|c|c|}
\hline 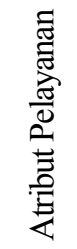 & 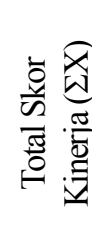 & 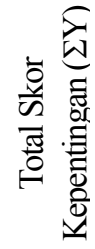 & 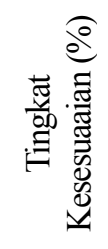 & : & 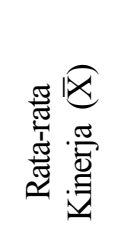 & 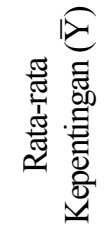 \\
\hline 1 & 1366 & 1734 & 78,78 & 10 & 3,40 & 4,34 \\
\hline 2 & 1448 & 1722 & 84,09 & 27 & 3,61 & 4,31 \\
\hline 3 & 1494 & 1691 & 88,35 & 35 & 3,74 & 4,23 \\
\hline 4 & 1420 & 1607 & 88,36 & 36 & 3,55 & 4,02 \\
\hline 5 & 1525 & 1766 & 86,35 & 31 & 3,81 & 4,42 \\
\hline 6 & 1522 & 1707 & 89,16 & 37 & 3,81 & 4,27 \\
\hline 7 & 1525 & 1672 & 91,21 & 38 & 3,82 & 4,18 \\
\hline 8 & 1473 & 1719 & 85,69 & 30 & 3,68 & 4,30 \\
\hline 9 & 1439 & 1658 & 86,79 & 32 & 3,60 & 4,15 \\
\hline 10 & 1304 & 1702 & 76,62 & 6 & 3,26 & 4,26 \\
\hline 11 & 1067 & 1682 & 63,44 & 1 & 2,68 & 4,21 \\
\hline 12 & 1208 & 1531 & 78,90 & 11 & 3,02 & 3,83 \\
\hline 13 & 1091 & 1592 & 68,53 & 2 & 2,73 & 3,98 \\
\hline 14 & 1185 & 1432 & 82,75 & 22 & 2,96 & 3,58 \\
\hline 15 & 1260 & 1624 & 77,59 & 8 & 3,15 & 4,06 \\
\hline 16 & 1459 & 1663 & 87,73 & 34 & 3,65 & 4,16 \\
\hline 17 & 1450 & 1663 & 87,19 & 33 & 3,63 & 4,16 \\
\hline 18 & 1404 & 1779 & 78,92 & 12 & 3,50 & 4,45 \\
\hline 19 & 1322 & 1769 & 74,73 & 5 & 3,32 & 4,42 \\
\hline 20 & 1329 & 1733 & 76,69 & 7 & 3,33 & 4,33 \\
\hline 21 & 1423 & 1743 & 81,64 & 18 & 3,55 & 4,36 \\
\hline 22 & 1439 & 1721 & 83,61 & 26 & 3,59 & 4,30 \\
\hline 23 & 1421 & 1756 & 80,92 & 15 & 3,54 & 4,39 \\
\hline 24 & 1396 & 1688 & 82,70 & 21 & 3,48 & 4,22 \\
\hline 25 & 1420 & 1748 & 81,24 & 17 & 3,53 & 4,37 \\
\hline 26 & 1464 & 1804 & 81,15 & 16 & 3,65 & 4,51 \\
\hline 27 & 1439 & 1754 & 82,04 & 20 & 3,60 & 4,39 \\
\hline 28 & 1239 & 1737 & 71,33 & 4 & 3,09 & 4,34 \\
\hline 29 & 1418 & 1698 & 83,51 & 25 & 3,54 & 4,25 \\
\hline 30 & 1432 & 1692 & 84,63 & 28 & 3,58 & 4,23 \\
\hline 31 & 1406 & 1686 & 83,39 & 23 & 3,51 & 4,22 \\
\hline 32 & 1416 & 1802 & 78,58 & 9 & 3,53 & 4,51 \\
\hline 33 & 1225 & 1761 & 69,56 & 3 & 3,06 & 4,40 \\
\hline 34 & 1454 & 1824 & 79,71 & 14 & 3,63 & 4,56 \\
\hline 35 & 1449 & 1824 & 79,44 & 13 & 3,62 & 4,56 \\
\hline 36 & 1477 & 1733 & 85,23 & 29 & 3,68 & 4,33 \\
\hline 37 & 1404 & 1712 & 82,01 & 19 & 3,49 & 4,28 \\
\hline 38 & 1402 & 1680 & 83,45 & 24 & 3,49 & 4,20 \\
\hline \multicolumn{2}{|l|}{ Total } & & & & 131,54 & 162,02 \\
\hline \multicolumn{2}{|c|}{ Rata-rata } & & 81,21 & & $\begin{array}{c}3,46 \\
(\overline{\bar{X}})\end{array}$ & $\begin{array}{c}4,26 \\
(\overline{\bar{Y}})\end{array}$ \\
\hline
\end{tabular}

Sumber: Hasil Olah Data (2015) 
Diketahui rata-rata nilai tingkat kesesuaian yang diperoleh adalah $81,21 \%$ dimana nilai ini menunjukkan bahwa secara keseluruhan atribut pelayanan angkutan penyeberangan masih belum sesuai dengan harapan pengguna jasa karena nilai tingkat kesesuaian tidak mencapai $100 \%$ sehingga masih diperlukan adanya perhatian dan perbaikan dari operator angkutan penyeberangan untuk peningkatan kinerja pelayanan yang diberikan.

\section{Tingkat Kinerja dan Kepentingan Pengguna Jasa Angkutan Penyeberangan Lintas Kariangau-Penajam}

Persepsi pengguna jasa terhadap atribut pelayanan yang diberikan oleh operator angkutan penyeberangan merupakan dasar penentu penilaian tingkat kinerja pelayanan dari angkutan penyeberangan yang ada apakah sudah baik atau belum yaitu dengan membandingkan nilai rata-rata kinerja pelayanan yang diberikan oleh penyedia jasa untuk setiap atribut pelayanan $(\overline{\mathrm{X}})$ terhadap rata-rata kinerja keseluruhan atribut pelayanan $(\overline{\bar{X}})$ dimana dari Tabel 3 diketahui besarnya nilai $\overline{\bar{X}}=3,46$. Sebagai dasar penentu penilaian tingkat kepentingan pengguna jasa terhadap pelayanan angkutan penyeberangan dilakukan dengan membandingkan nilai rata-rata kepentingan pengguna jasa untuk semua atribut pelayanan $(\overline{\mathrm{Y}})$ terhadap rata-rata kepentingan keseluruhan atribut pelayanan $(\overline{\bar{Y}})$ dimana dari Tabel 3 diketahui besarnya nilai $\overline{\bar{Y}}=4,26$. Nilai $\overline{\bar{X}}$ dan $\overline{\bar{Y}}$ selanjutnya diplotkan dalam diagram kartesius sebagai sumbu koordinat dan nilai rata-rata persepsi pengguna jasa terhadap kinerja $\overline{\mathrm{X}}$ dan kepentingan $\overline{\mathrm{Y}}$ pelayanan angkutan penyeberangan selanjutnya digunakan untuk melakukan analisis data dalam diagram kartesius metode IPA.

Gambar 4 menunjukkan hasil plotting atribut pelayanan dalam diagram kartesius metode IPA sehingga terlihat persebaran letak atribut-atribut pelayanan angkutan penyeberangan yang dikaji menurut persepsi pengguna jasa pada masing-masing kuadran metode IPA. Atribut-atribut pelayanan yang masuk pada tiap-tiap kuadran adalah sebagai berikut:

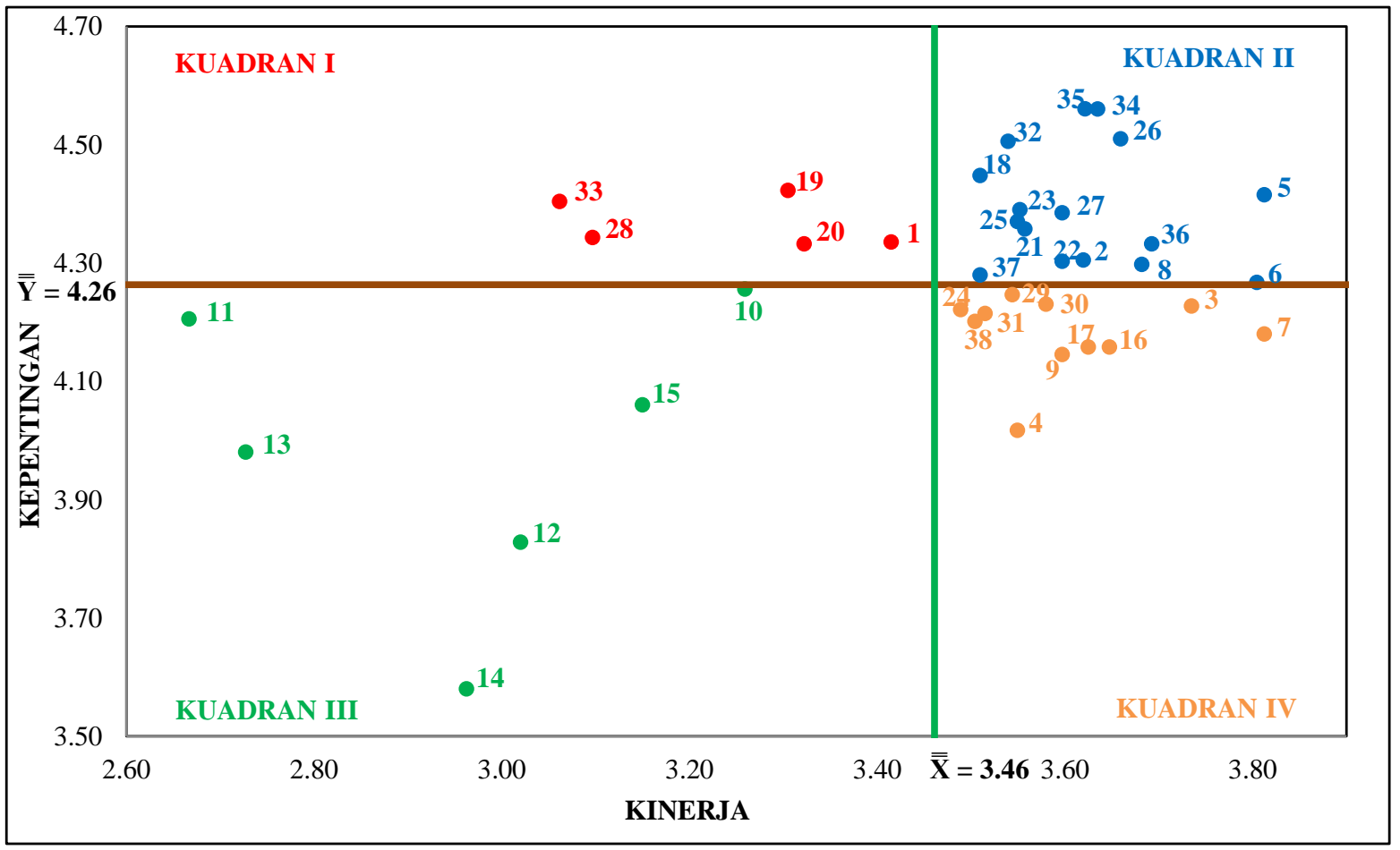

Gambar 4. Plotting atribut-atribut pelayanan angkutan penyeberangan dalam digram kartesius metode IPA Sumber: Hasil Analisis (2015)

\section{KUADRAN I (prioritas utama)}

1 Kebersihan toilet di dalam kapal

19 Ketepatan waktu tiba di pelabuhan tujuan
20 Ketepatan lama waktu pelayaran

28 Suhu udara dalam kapal

33 Adanya pemberitahuan/peragaan alatalat keselamatan di kapal 


\section{KUADRAN II (pertahankan prestasi)}

2 Kebersihan kapal

5 Ketersediaan tempat ibadah di dalam kapal

6 Jumlah tempat duduk yang disediakan

8 Kualitas tempat duduk

18 Ketepatan waktu keberangkatan

21 Jadwal perjalanan kapal

22 Kemampuan operator darat dan kru kapal dalam memberikan pelayanan secara cepat dan tepat kepada penumpang

23 Kemampuan kru kapal untuk menolong penumpang (memberikan bantuan kepada penumpang apabila dibutuhkan)

25 Kepedulian untuk standar pelayanan

26 Kenyamanan di dalam kapal

27 Kenyamanan dan keleluasaan tempat duduk dalam kapal

32 Kelengkapan alat-alat keselamatan di kapal

34 Keamanan di dalam kapal

35 Keamanan barang bawaan

36 Keramahan kru di dalam kapal

37 Perhatian secara khusus bila ada keluhan dari penumpang

\section{KUADRAN III (prioritas rendah)}

10 Kondisi tangga di kapal

11 Tersedianya ruang perawatan (klinik) untuk orang sakit

12 Tersedianya ruang terbuka untuk tempat santai/rekreasi (public area)

13 Tersedianya CCTV (kamera pemantau)

14 Tersedianya musik

15 Tarif penyeberangan

\section{KUADRAN IV (cenderung berlebihan)}

3 Kebersihan tempat duduk yang disediakan

4 Ketersediaan kantin/kafetaria di dalam kapal

7 Tersedia tempat duduk setiap saat

9 Gang/ruang jalan untuk orang melintas

16 Penampilan kru kapal

17 Antrian kendaraan naik dan turun kapal

24 Kemampuan kru kapal untuk menanggapi permintaan penumpang

29 Pengetahuan yang dimiliki kru awak kapal

30 Pelayanan bongkar muat kendaraan

31 Waktu bongkar muat kendaraan

38 Kepedulian operator darat dan kru kapal untuk memahami suasana hati

\section{Kepuasan Pengguna Jasa terhadap Pelayanan Angkutan Penyeberangan Lintas Kariangau-Penajam}

Tabel 5. Indeks Kepuasan Pengguna (CSI)

\begin{tabular}{|c|c|c|c|c|}
\hline 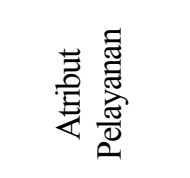 & 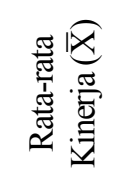 & 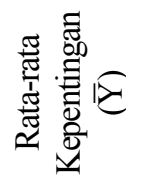 & 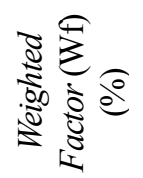 & 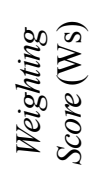 \\
\hline 1 & 3,40 & 4,34 & 2,68 & 0,09 \\
\hline 2 & 3,61 & 4,31 & 2,66 & 0,10 \\
\hline 3 & 3,74 & 4,23 & 2,61 & 0,10 \\
\hline 4 & 3,55 & 4,02 & 2,48 & 0,09 \\
\hline 5 & 3,81 & 4,42 & 2,72 & 0,10 \\
\hline 6 & 3,81 & 4,27 & 2,63 & 0,10 \\
\hline 7 & 3,82 & 4,18 & 2,58 & 0,10 \\
\hline 8 & 3,68 & 4,30 & 2,65 & 0,10 \\
\hline 9 & 3,60 & 4,15 & 2,56 & 0,09 \\
\hline 10 & 3,26 & 4,26 & 2,63 & 0,09 \\
\hline 11 & 2,68 & 4,21 & 2,60 & 0,07 \\
\hline 12 & 3,02 & 3,83 & 2,36 & 0,07 \\
\hline 13 & 2,73 & 3,98 & 2,46 & 0,07 \\
\hline 14 & 2,96 & 3,58 & 2,21 & 0,07 \\
\hline 15 & 3,15 & 4,06 & 2,51 & 0,08 \\
\hline 16 & 3,65 & 4,16 & 2,57 & 0,09 \\
\hline 17 & 3,63 & 4,16 & 2,57 & 0,09 \\
\hline 18 & 3,50 & 4,45 & 2,74 & 0,10 \\
\hline 19 & 3,32 & 4,42 & 2,73 & 0,09 \\
\hline 20 & 3,33 & 4,33 & 2,67 & 0,09 \\
\hline 21 & 3,55 & 4,36 & 2,69 & 0,10 \\
\hline 22 & 3,59 & 4,30 & 2,66 & 0,10 \\
\hline 23 & 3,54 & 4,39 & 2,71 & 0,10 \\
\hline 24 & 3,48 & 4,22 & 2,60 & 0,09 \\
\hline 25 & 3,53 & 4,37 & 2,70 & 0,10 \\
\hline 26 & 3,65 & 4,51 & 2,78 & 0,10 \\
\hline 27 & 3,60 & 4,39 & 2,71 & 0,10 \\
\hline 28 & 3,09 & 4,34 & 2,68 & 0,08 \\
\hline 29 & 3,54 & 4,25 & 2,62 & 0,09 \\
\hline 30 & 3,58 & 4,23 & 2,61 & 0,09 \\
\hline 31 & 3,51 & 4,22 & 2,60 & 0,09 \\
\hline 32 & 3,53 & 4,51 & 2,78 & 0,10 \\
\hline 33 & 3,06 & 4,40 & 2,72 & 0,08 \\
\hline 34 & 3,63 & 4,56 & 2,81 & 0,10 \\
\hline 35 & 3,62 & 4,56 & 2,81 & 0,10 \\
\hline 36 & 3,68 & 4,33 & 2,67 & 0,10 \\
\hline 37 & 3,49 & 4,28 & 2,64 & 0,09 \\
\hline 38 & 3,49 & 4,20 & 2,59 & 0,09 \\
\hline WeightedTotal & & & & 3,47 \\
\hline CSI & \multicolumn{3}{|c|}{$=(3,47 / 5) * 100 \%=$} & $69 \%$ \\
\hline
\end{tabular}

Tabel 5 menjelaskan bahwa berdasarkan hasil perhitungan CSI terhadap skor rata-rata kinerja dan kepentingan diperoleh besarnya nilai CSI adalah 69\%. Nilai tersebut berada pada rentang nilai $0,66-0,80$ yang masuk dalam 
kriteria Puas. Sehingga dapat dikatakan bahwa pengguna jasa angkutan penyeberangan merasa puas terhadap kinerja seluruh atribut pelayanan angkutan penyeberangan lintas KariangauPenajam, Balikpapan.

\section{Solusi Alternatif Untuk Atribut Pelayanan di Kuadran I (Prioritas Utama)}

Solusi alternatif untuk peningkatan pelayanan angkutan penyeberangan berdasarkan persepsi pengguna jasa terkait dengan kebersihan toilet di kapal adalah dengan menempatkan cleaning service yang standby bertugas menjaga kebersihan toilet juga dengan selalu menyampaikan melalui pengeras suara agar senantiasa menjaga kebersihan selama pelayaran setiap kapal mau berangkat maupun tiba di pelabuhan tujuan. Untuk ketepatan waktu tiba di pelabuhan tujuan dan ketepatan lama waktu pelayaran dapat ditingkatkan dengan menjalin komunikasi antar kapal yang selalu update posisi sehingga nakhoda bisa mengatur kecepatan kapal agar bisa memenuhi time table yang telah ditetapkan. Untuk suhu udara di dalam kapal dapat ditingkatkan dengan penambahan unit air conditioner (AC) ataupun fan dengan diameter fan yang disesuaikan dengan luas ruangan kapal yang dilayani. Adanya pemberitahuan/peragaan alat-alat keselamatan di kapal dapat dilakukan dengan peragaan langsung oleh crew kapal atau melalui rekaman visual yang dapat dilihat oleh seluruh penumpang.

\section{KESIMPULAN DAN SARAN}

\section{Kesimpulan}

Masih adanya keluhan masyarakat terhadap kinerja pelayanan angkutan penyeberangan lintas Kariangau - Penajam yang menyatakan bahwa waktu penggunaan sistem pelayanan penyeberangan lama sehingga penumpang harus antri di pelabuhan atau lama di atas kapal menunggu bongkar muat menyebabkan diberlakukannya sistem operasional kapal yang baru yaitu pola 10:2 (10 operasi dan 2 standby) menggantikan pola yang lama 8:4 (8 operasi dan 4 standby). Metode untuk mengetahui kinerja pelayanan tersebut dengan melakukan survei terhadap persepsi kepuasan pengguna jasa. Hasil analisis menyebutkan bahwa kinerja pelayanan angkutan penyeberangan masih perlu penanganan dan perbaikan. Hasil IPA menjelaskan bahwa atribut pelayanan yang menempati prioritas utama untuk diperbaiki adalah atribut kebersihan kamar mandi/WC di kapal, ketepatan waktu tiba di pelabuhan tujuan, ketepatan lama waktu pelayaran, suhu udara di dalam kapal dan Adanya pemberitahuan/peragaan alat-alat keselamatan di kapal. Sedangkan beberapa atribut pelayanan yang perlu dipertahankan kinerjanya diantaranya kebersihan kapal, ketersediaan tempat ibadah di dalam kapal dan jumlah tempat duduk yang disediakan. Atribut pelayanan dengan prioritas rendah terdiri dari 6 atribut pelayanan. Sementara itu atribut pelayanan yang dianggap berlebihan terdiri dari 11 atribut pelayanan.

Hasil analisis indeks kepuasan pengguna jasa diperoleh nilai CSI sama dengan $69 \%$ yang menunjukkan bahwa kinerja pelayanan angkutan penyeberangan yang dirasakan oleh pengguna jasa masuk dalam kriteria Puas.

\section{Saran}

Sebagai saran untuk kajian dan penelitian selanjutnya, diperlukan keterlibatan kru kapal sebagai responden sehingga dapat diketahui persepsinya terhadap pelayanan yang telah diberikan sebagai masukan berharga kepada operator kapal sebagai upaya mempertahankan dan meningkatkan kinerja pelayanan kepada pengguna jasa.

\section{DAFTAR PUSTAKA}

Adisasmita, R. 2013. Pembangunan Ekonomi Maritim, Yogyakarta: Graha Ilmu.

Anonim. 2008. Undang-Undang Republik Indonesia Nomor 17 Tahun 2008 Tentang Pelayaran. Jakarta.

Anonim. 2015. Peraturan Menteri Perhubungan Republik Indonesia Nomor PM 39 Tahun 2015 tentang Standar Pelayanan Penumpang Angkutan Penyeberangan. Jakarta.

Anonim. 2012. Peraturan Direktur Jenderal Perhubungan Darat Nomor: SK.4608/AP.005/DRJD/2012 tentang Standar Pelayanan Minimal Angkutan Penyeberangan. Jakarta.

Anonim. 2010. Peraturan Direktur Jenderal Perhubungan Darat Nomor: SK.242/HK.104/DRJD/2010 tentang Pedoman Teknis Manajemen Lalu Lintas Penyeberangan. Jakarta.

Anonim. 2014. Salinan Keputusan Gubernur Kalimantan Timur Nomor 
561/K.739/2014 tentang Penetapan Upah Minimum Kota Balikpapan Tahun 2015. Samarinda.

Anonim. 2015. Kota Balikpapan Dalam Angka 2015. BPS Kota Balikpapan. Kota Balikpapan.

Fitriani, E, 2011, Analisis Penetapan Tarif Disesuaikan dengan Ekspektasi Penumpang terhadap Pelayanan Kapal RoRo Lintas Merak-Bakauheni, Tesis. Jakarta: Universitas Indonesia.

Parasuraman, A., Zeithaml, VA., Berry, LL. 1988. Servqual : A Multiple-Item Scale for Measuring Consumer Perceptions of Service Quality. Journal of Retailing Volume 64 Number 1 page 12-40.

Ruta, K.S. 2014. Analisis Tingkat Pelayanan Stasiun Lempuyangan Terhadap Kepuasan Pengguna Jasa Dengan Integrasi Metode Importance Performance Analysis (IPA) dan Model Kano. Tesis. Universitas Gadjah Mada, Yogyakarta.

Siahaan, B.L. 2014. Kajian Kinerja Pelayanan dan Pemilihan Moda Angkutan Penyeberangan Rute Kupang-Rote. Tesis, Universitas Brawijaya, Malang.

Siregar, S. 2013. Metode Penelitian Kuantitatif Dilengkapi Dengan Perbandingan Perhitungan Manual \& SPSS, Kencana Prenada Media Group, Jakarta.

Sedayu, A., Sulistio, H., Wicaksono, A. 2013. Prioritas Peningkatan Kualitas Pelayanan Terminal Joyoboyo Surabaya. The $16^{\text {st }}$ FSTPT International Symposium, UMS Surakarta.

Supranto, J. 2001. Pengukuran Tingkat Kepuasan Pelanggan (Cetakan Kedua). Jakarta: Rineka Cipta 